\title{
Lungekreft hos røykere og aldri-røykere
}

\author{
Sammendrag \\ Bakgrunn. Lungekreft er den vanligste \\ kreftrelaterte dødsårsak hos begge \\ kjønn. De fleste tilfeller er forårsaket \\ av tobakksrøyk, men estimater viser at \\ $15-20 \%$ av lungekrefttilfellene i den \\ vestlige verden ikke er røykeassossiert. \\ Nye molekylære og kliniske studier \\ indikerer at lungekreft som oppstår \\ hos aldri-røykere, har visse karakteris- \\ tika som er forskjellige fra lungekreft \\ som oppstår hos røykere. I denne artik- \\ kelen vil vi beskrive forskjellene mel- \\ lom lungekreft hos røykere og aldri- \\ røykere.
}

\section{Materiale og metode. Artikkelen er basert på ikke-systematiske litteratur- søk i PubMed.}

Resultater. Det er estimert at tobakksuavhengig lungekreft er den sjuende hyppigste kreftformen på verdensbasis. Det kan påvises en rekke molekylærbiologiske og kliniske forskjeller ved lungekreft hos røykere og aldri-røykere. Blant aldri-røykende er $62 \%$ av svulstene klassifisert som adenokarsinomer og $18 \%$ plateepitelkarsinom, mens det blant røykere er $19 \%$ adenokarsinomer og $53 \%$ plateepitelkarsinomer. Genet K-Ras er ofte mutert i svulster hos røykere, men sjelden i svulster hos aldri-røykere. Genet EGFR er hyppigere mutert i svulster hos aldri-røykere. Også når det gjelder alder- og kjønnsfordeling, terapirespons samt prognose, er det påvist forskjeller mellom røykere og aldrirøykere.

Fortolkning. Tobakksuavhengig lungekreft bør trolig oppfattes som en annen sykdomsentitet enn lungekreft forårsaket av tobakk. Dette kan ha både prognostiske og behandlingsmessige konsekvenser.

\section{Åslaug Helland}

aslaug.helland@radiumhospitalet.no

Odd Terje Brustugun

Onkologisk avdeling

Radiumhospitalet

Oslo universitetssykehus, Rikshospitalet 0310 Oslo

Lungekreft er den tredje hyppigste kreftform i Norge, med over 2500 nye tilfeller årlig. I Norge er fem års relativ overlevelse $9,7 \%$ for menn og 14,2\% for kvinner (1).

På verdensbasis er det estimert at $15 \%$ av lungekrefttilfellene hos menn og $53 \%$ av lungekrefttilfellene hos kvinner ikke skyldes røyking, og dette tilsvarer ca. $25 \%$ av alle lungekrefttilfeller (2). I den vestlige verden er ca. $15-20 \%$ av lungekrefttilfellene ikke tobakksassosiert. Dersom man ser på lungekreft hos aldri-røykere separat, utgjør det den sjuende vanligste kreftdødsårsaken på verdensbasis. I Norge dør flere årlig av ikkerøykeindusert lungekreft enn av for eksempel livmorhals- eller testikkelkreft.

Nye data tyder på at lungekreft som oppstår hos aldri-røykere bør ses på som en egen entitet, og dette vil kunne ha behandlingsmessige implikasjoner. Lungekreft hos røykere versus aldri-røykere har ulike molekylære og kliniske karakteristika samt ulik terapirespons, og dette vil diskuteres i denne artikkelen. Vi vil sammenlikne årsaker, disposisjon og prognose for lungekreft hos røykere og aldri-røykere.

\section{Materiale og metode}

Artikkelen er basert på ikke-systematisk litteratursøk i PubMed.

\section{Tobakksrøyk}

Epidemiologiske og biologiske data viser at insidensen av lungekreft følger røykeepidemien. Lungekreftinsidensen ser ut til å øke 20 år etter økningen i antall røykere (3). Lungekreft var uvanlig før tobakksrøyking ble populært. I 1878 utgjorde maligne lungesvulster kun $1 \%$ av krefttilfellene sett ved autopsi, mens det i 1918 var $10 \%$ (4).

Inntil nylig var det en stor overvekt av mannlige lungekreftpasienter, men etter hvert som kvinneandelen har steget blant røykerne, har også andelen kvinner med lungekreft $ø k t$. Lungekreft passerte brystkreft som den hyppigste kreftrelaterte dødsårsak hos norske kvinner i 2005. Man har tidligere antatt at kvinner er mer utsatt for røykeindusert lungekreft, men nyere studier viser at kvinner og menn med lik sigaretteksposisjon har lik risiko for å utvikle lungekreft (5).
I Canada har man estimert at mannlige røykere har en livstidsrisiko for å utvikle lungekreft på $17 \%$, mens tilsvarende tall for aldri-røykende menn er 1,3\% (6). Når man slutter å røyke, faller risikoen jevnt over tid, og det er estimert en halvering av risiko etter ca. ti år (7). Størst er nedgangen for småcellet lungekreft, mens risikoreduksjonen er mindre for adenokarsinom. Risiko for lungekreft hos tidligere røykere vil likevel hele livet være høyere enn hos aldri-røykere. Dette er grunnen til at vi i denne artikkelen bruker begrepet aldri-røykere i stedet for ikkerøykere.

Tverdal \& Bjartveit har i likhet med utenlandske grupper publisert studier som viser at den helsemessige gevinsten av å redusere tobakksforbruket er begrenset, sett i forhold til røykestopp. En halvering av sigarettforbruket hos storrøykere gir ingen endring $\mathrm{i}$ risiko for tidlig død, men gir en liten endring i risiko for lungekreft (8).

Det er sannsynlig at en liten del av lungekreft hos røykere ikke er tobakksindusert. Disse tilfellene er vanskelige å definere, og således vanskelige å studere. Studier som er gjort for å undersøke forskjeller mellom tobakksindusert og tobakksuavhengig lungekreft er derfor i hovedsak gjort på forskjeller mellom lungekreft hos aldri-røykende versus røykende pasienter.

\section{Risikofaktorer for lungekreft hos aldri-røykere Passiv røyking}

I forlengelsen av den åpenbare årsakssammenhengen mellom aktiv røyking og lungekreftutvikling er sammenhengen mellom passiv røyking og lungekreft undersøkt. Risikoestimatene er ikke entydige, men en stor metaanalyse konkluderte nylig med at det er en kausal sammenheng mellom passiv røyking og utvikling av lungekreft (9). En nyere

\section{Hovedbudskap}

- Tobakksuavhengig lungekreft er den sjuende hyppigste kreftform på verdensbasis

- Lungekreft hos røykere versus aldri-røykere har en rekke ulike karakteristika

- Lungekreft hos aldri-røykere bør oppfattes som en annen sykdomsentitet enn lungekreft hos røykere 
Tabell 1 Viktige ulikheter mellom lungekreft hos røykere og hos aldri-røykere

\begin{tabular}{|c|c|c|}
\hline & Lungekreft hos aldri-røykere & Lungekreft hos røykere \\
\hline Kjønnsforskjeller & Hyppigst hos kvinner & Ingen klar kjønnsforskjell \\
\hline Symptomer ved diagnose & Hoste, dyspné, vekttap & Oftere ingen symptomer \\
\hline Histologisk type & Adenokarsinom vanligst & Plateepitelkarsinom vanligst \\
\hline Ekstra kromosmarm 16p & Hyppig & Mindre hyppig \\
\hline EGFR-aktiverende mutasjon & Hyppig & Sjelden \\
\hline K-Ras-mutasjon & Sjelden & Hyppigere \\
\hline TP53-mutasjon & Oftest transisjon ${ }^{1}$ & Oftest transversjon ${ }^{2}$ \\
\hline Metylering av gener & P16-metylering sjelden & P16-metylering hyppig \\
\hline Terapirespons & $\begin{array}{l}\text { Ofte god respons på tyrosin- } \\
\text { kinasehemmer }\end{array}$ & $\begin{array}{l}\text { Dårligere respons på tyrosin- } \\
\text { kinasehemmer }\end{array}$ \\
\hline
\end{tabular}

stor europeisk studie viste at også passiv røyking i barneårene medfører en signifikant økning i risiko for utvikling av lungekreft i voksen alder (10).

\section{Radon}

Radon er en radioaktiv gass som produseres under nedbrytning av uran i fjell og jord. Det er svært lave konsentrasjoner av radon utendørs, men gassen kan akkumuleres innendørs ved blant annet å sive inn gjennom sprekker i grunnmur. De høyeste radonkonsentrasjonene fines i urangruver, og epidemiologiske studier blant gruvearbeidere har etablert radon som en årsak til lungekreft. Ved inhalasjon vil radon resultere i alfastråling som skader DNA. Forskning konkluderer med at radon i hjem gir en liten økning i kreftrisiko blant både røykere og aldrirøykere og at ca. $2 \%$ av alle krefttilfeller i Europa er forårsaket av dette (11). Høyest økning observeres blant røykere, da radon og røyk har en synergistisk effekt.

\section{Asbest}

Den karsinogene effekten av asbesteksposisjon er trolig mediert ved at fibrene påvirker cellenes mitoseapparat og gir kromosomale endringer, som store delesjoner. I tillegg øker asbestfibrene nivået av frie radikaler, noe som leder til både fibroseutvikling og økt sannsynlighet for karsinogene mutasjoner. Trolig virker asbest sammen med røyking ved å øke mutagenisiteten av karsinogener i tobakk. Det resulterer i en synergistisk effekt ved eksposisjon for begge (12).

\section{Østrogen}

Det er funnet østrogenreseptorer (hovedsakelig betatype) i vev fra både normal lunge og lungekreft (13). Østrogenreseptor er en vekstfaktor som kan føre til økt cellulær proliferasjon og tumorvekst, og østrogener har vært mistenkt å kunne være en bidragsyter også i utvikling av lungekreft. Ferske data tyder imidlertid på at hormonbehandling gir minsket risiko for lungekreft hos postmenopausale kvinner (14). Progesteronreseptor er i en studie funnet i nesten $50 \%$ av svulstene og var assosiert med bedret prognose (15). Foreløpig er hormoners rolle i lungekreftutvikling omdiskutert.

\section{Virus}

Humant papillomvirus (HPV) infiserer epitelceller og kan overføres intrauterint eller seksuelt. Over hundre HPV-serotyper er identifisert, og noen av disse er assosiert med kreftutvikling i livmorhals, hud, spiserør og i øvre luftveier. Det er i løpet av de siste årene kommet rapporter som antyder at humant papillomvirus også spiller en rolle ved lungekreft (16). Viruset kan påvises i tumorvev fra ca. $20 \%$ av alle lungekrefttilfeller, og man har funnet HPV-onkoproteinene E6 og E7 i HPV-positive lungekreftsvulster. E6 og E7 fra HPV-type 16 og 18 er vist å inneha evnen til å immortalisere humane epitelceller fra trachea. Videre er det interessant at lungekreft er den hyppigste sekundærcancer etter behandling for livmorhalskreft, også etter den røykeuavhengige adenokarsinomvarianten av cervixcancer, med en spesielt høy risiko for lungekreft de første årene etter livmorhalskreftdiagnosen (17). Det er også vist at risiko for malign utvikling av en HPVinfeksjon er assosiert med røyking. Dette kan være årsaken til at røykere utvikler begge kreftformer. Ytterligere studier må til for å kunne belyse om humant papillomvirus har en kausal rolle i kreftutviklingen i lunge.

Også Epstein-Barr-virus (EBV) har vært diskutert som årsaksfaktor ved lungekreft, men disse funnene er omdiskutert (18).

\section{Matos og røyk}

Epidemiologiske studier viser en svært høy insidens av lungekreft hos kvinner i visse lite tobakksbelastede regioner av Asia, opptil 90/100 000 (19), mot 22/100 000 i den norske kvinnelige populasjonen. Dette kan ha flere årsaker. Tradisjonell asiatisk matlaging involverer steking av mat i olje på høye temperaturer, som medfører mye stekeos. Det er vist at slik os kan indusere mutasjoner og at den inneholder karsinogene polysykliske aromatiske hydrokarboner og aldehyder (20). I tillegg fyres det i disse områdene med kull og ved, og ettersom ovnene ofte mangler pipe, blir rommene svært røykfylte. Slik røyk har vist seg å inneholde kreftfremkallende stoffer og kan også være en årsak til lungekreftutvikling hos aldri-røykende (21).

\section{Andre faktorer}

En rekke andre faktorer er diskutert som mulige årsaker til lungekreft. Noen årsaksforhold er etablert, som nikkeleksponering i arbeidslivet, vist $i$ en norsk studie (22). En nederlandsk studie viste at personer utsatt for høy luftforurensning fra trafikk hadde økt risiko for lungekreft, justert for røykevaner (23).

\section{Genetisk disposisjon}

Det er sannsynlig at ulike genvarianter påvirker både hvor avhengig man blir av røyking og sykdomsrisikoen forbundet med røykingen. Konstitusjonell variasjon i både reparasjon og detoksifisering av karsinogener vil også påvirke risikoen for lungekreftutviklig hos aldri-røykere. Man har påvist at aldri-røykende lungekreftpasienter har redusert evne til å reparere DNA-skader i forhold til friske aldri-røykende kontrollpersoner (24), men man har så langt ikke kunnet påvise arvelige gener som gir økt risiko for lungekreft hos aldri-røykere.

Etter karakteriseringen av det humane genom er det publisert tre store genomvide assosiasjonsstudier om risiko for utvikling av lungekreft (25-27). I alle tre finner man en assosiasjon til kromosomområde 15q24/ 15q25.1. Dette området inneholder mange gener, blant annet gener som koder for deler av nikotinacetylkolinreseptoren. To av studiene hadde inkludert aldri-røykere (definert som røykt $<100$ sigaretter) i analysene, men det var et lite antall, og studiene kom til motsatte konklusjoner. Hung og medarbeidere inkluderte 352 aldri-røykere og fant samme assosiasjon blant disse som hos røykere (26), mens Amos og medarbeidere ikke fant noen slik assosiasjon, men hadde kun 125 aldri-røykere med $i$ analysene (25).

\section{Genforandringer i svulsten}

Karsinogenese er en stegvis prosess der genetiske forandringer akkumuleres, og man får en invasiv svulst som har evne til å metastasere. Man vet mye om molekylære endringer i lungekreft, og man vet at både tumorsuppressorgener, onkogener og reparasjonsgener er involvert. Dette er beskrevet tidligere i Tidsskriftet (28), og vi vil her fokusere på forskjellene i genetiske forandringer i svulster hos røykere og aldri-røykere (tab 1).

\section{Kromosomale endringer}

Flere studier har sett på store kromosomale endringer i lungekreftsvulster både hos aldrirøykere og røykere. Karyotypiske endringer innebærer ofte multiple numeriske og strukturelle endringer (29). Numeriske endringer omfatter tap av kromosom 9 og 13 samt 
trisomi 7. I svulster hos menn er tap av Y-kromosomet vanlig. Tap av genetisk materiale pga. ubalanserte translokasjoner omfatter så og si alle kromosomer. Ekstra kromosomarm 16p er sett oftere hos aldri-røykere enn hos røykere, og likeens $20 \mathrm{q}$, mens $3 \mathrm{p} 21$ ser ut til å være vanligst hos røykeindusert lungekreft (30).

\section{EGFR}

Epidermal vekstfaktorreseptor (EGFR) er en reseptortyrosinkinase og aktiveres av spesifikke ligander. Aktivering av EGFRreaksjonsveien er viktig i celleproliferasjon, apoptoseregulering, angiogenese og invasjon. En karakteristisk endring i lungekreft er overuttrykk eller mutasjon av EGFR-proteinet. Dette er forsøksvis utnyttet klinisk, med EGFR-hemmere som erlotinib og gefitinib.

EGFR-genet er hyppigere mutert i lungekreftsvulster hos aldri-røykere enn hos røykere (tab 1). En metaanalyse konkluderte med at $45 \%$ av aldri-røykere hadde slike mutasjoner mot kun $7 \%$ av røykere (31). Funn tyder også på at frekvensen av EGFR-mutasjoner faller med økende antall sigaretter og er knapt sett hos pasienter med mer enn 75 pakkeår (32).

\section{K-Ras}

I motsetning til EGFR er mutasjoner i onkogenet $K$-Ras-genet sjelden hos aldri-røykere (33). K-Ras er nedstrøms for EGFR, og mutasjoner i disse to genene er nærmest gjensidig ekskluderende. Funn tyder på at K-Rasmutasjoner er en negativ prediktiv faktor for respons på tyrosinkinaseinhibitorer. ERBB2og $B R A F$-genene er også sett mutert i adenokarsinomer (34), og da noe hyppigere hos aldri-røykere.

\section{TP53}

TP53-proteinet virker som en transkripsjonsfaktor og regulerer en rekke ulike prosesser, deriblant apoptose og respons på DNA-skade. Tumorsuppressorgenet TP53 er mutert $\mathrm{i}$ $40-60 \%$ av ikke-småcellet lungekreft (35). Slike mutasjoner er til stede i svulster både hos røykere og hos aldri-røykere, men er hyppigere sett hos røykere (36). I tillegg er mutasjonstypen og mutasjonsspekteret ulikt mellom røykere og aldri-røykere. Tobakksassosierte svulster er karakterisert av en høy frekvens av transversjonsmutasjoner, der purin (G eller A) blir erstattet av pyrimidin (C eller T). Hos aldri-røykere er transisjoner dominerende (purin til purin eller pyrimidin til pyrimidin). Dette bekrefter ulike mekanismer bak lungekreftutvikling hos aldrirøykere versus røykere.

\section{Metylering}

Epigenetiske forandringer som metylering er, i motsetning til mutasjoner og delesjoner, reversible. Metylering av cytosin i såkalte CpG-øyer i promotorregionen til spesifikke gener kan føre til at dette genet blir «slått av», og proteinet blir dermed ikke uttrykt. Ved lungekreft hos røykere er det sett mer metylering enn ved ikke-røykeassosiert lungekreft. Man har funnet at metylering av genene $p 16$ (CDKN2A) og $A P C$ er vanligere hos røykere, og graden av metylering er avhengig av mengden røyk (37) (tab 1). Motsatt er det hos aldri-røykere sett økt promotorhypermetylering av reparasjonsgenene $h M L H 1$ og hMSH2 og derav redusert uttrykk av disse proteinene (38).

\section{MiRNA}

Små ikke-kodende RNA-biter, såkalt mikroRNA (miRNA), regulerer proteinuttrykket $i$ celler via hybridisering med komplementære mRNA-sekvenser. Hver av de over 1000 ulike miRNA kan kontrollere opptil 200 forskjellige mRNA. MiRNA er dermed den største klassen av genregulatorer. MiRNA-gener er i stor grad lokalisert i fragile regioner av genomet og kan være en viktig faktor i kreftutvikling. Slike fragile områder er utsatt for kopitallabnormaliteter, som gir enten tap eller amplifisering av spesifikke sekvenser. I tillegg er det påvist polymorfier også innen miRNA-genene, som fører til ytterligere variasjon i uttrykket.

MiRNA er ulikt uttrykt i lungekreftceller versus normalceller og er involvert $i$ interaksjoner mellom tumor og vert, som angiogenese, invasjons- og metastaseringspotensial (39). MiRNA er også involvert i reguleringen av TP53, og det er på bakgrunn av omtalen av TP53 i avsnittet over rimelig å anta at det også her er forskjeller mellom røykere og ikke-røykere (40). Nylig er det vist at visse polymorfismer av miRNA-familien Let-7, som regulerer K-Ras, disponerer for lungekreft hos røykere som røyker moderate mengder tobakk ( $<40$ pakkeår), mens det ikke var noen korrelasjon hos storrøykere. Dette kan forklares med at en endret disposisjon for lungekreft overskygges av den massive DNA-skaden som påføres i slike tilfeller (41).

\section{Kliniske ulikheter}

Lungekreft hos aldri-røykere er karakterisert av en noe lavere gjennomsnittsalder ved diagnose: 53,6 år, mot 66,2 år i røykergruppen $i$ et materiale fra USA (42). Videre er det blant ikke-røykerne en overhyppighet av kvinner. Adenokarsinomer er den vanligste histologiske typen hos aldri-røykere (tab 1). I en studie fant man $62 \%$ adenokarsinomer og $18 \%$ plateepitelkarsinom hos aldri-røykende kvinner, mens det blant røykere var $19 \%$ adenokarsinomer og $53 \%$ plateepitelkarsinomer (21).

Aldri-røykere har hyppigere symptomer på diagnosetidspunktet enn røykere, spesielt hoste, dyspné og vekttap (42), men studier tyder likevel på at lungekreft blir diagnostisert $i$ et mer langtkommet stadium hos aldrirøykere enn hos røykere. I asiatiske land synes aldri-røykere å bli diagnostisert tidligere enn røykere (21).

Flere studier har påvist en bedre overle- velse hos aldri-røykende pasienter enn hos pasienter med røykeindusert lungekreft når samme stadier sammenliknes. I tillegg forverres overlevelsen med økende antall pakkeår hos røykere (42).

Det er ikke påvist noen signifikant forskjell i respons til cytotoksisk kjemoterapi mellom røykere og aldri-røykere, men når det gjelder behandling med tyrosinkinasehemmere, er det vist klare forskjeller. Aldrirøykere hadde signifikant bedre respons enn røykere og tidligere røykere ved behandling med gefitinib (36\% mot $8 \%, p<0,001)(43$, 44). Liknende resultater er vist for erlotinib, med responsrater på $24,7 \%$ mot $3,9 \%$ $(\mathrm{p}<0,001)(45)$.

\section{Konklusjon}

Risikoen for å få lungekreft er mangedoblet ved tobakksrøyking, men også aldri-røykere får sykdommen. Både betydningen av miljøfaktorene som påvirker risikoen samt de molekylære forandringene man ser i svulsten, ser ut til å være noe ulike hos røykere og aldrirøykere. Dette tyder på at prosessen bak kreftutviklingen er forskjellig. I tillegg ser vi at behandlingsresponsen påvirkes av molekylære karakteristika i svulsten, og sannsynligvis også i pasienten.

I de siste årene har vi opplevd en kunnskapseksplosjon om molekylære endringer og karakteristika ved kreft. Kan hende er tiden inne for å benytte kunnskapen vi har om forskjellene mellom lungekreft hos røykere og aldri-røykere i kliniske studier, for så å kunne gi en mer skreddersydd terapi.

Oppgitte interessekonflikter: Ingen

\section{Litteratur}

1. Cancer in Norway 2007. Oslo: Kreftregisteret, 2008

2. Parkin DM, Bray F, Ferlay J et al. Global cancer statistics, 2002. CA Cancer J Clin 2005; 55: 74- 108.

3. Alberg AJ, Samet JM. Epidemiology of lung cancer. Chest 2003; 123: 21-49S.

4. Witschi H. A short history of lung cancer. Toxicol Sci 2001; 64: 4-6

5. Freedman ND, Leitzmann MF, Hollenbeck AR et al. Cigarette smoking and subsequent risk of lung cancer in men and women: analysis of a prospectve cohort study. Lancet Oncol 2008; 9: 649-56.

6. Villeneuve PJ, Mao Y. Lifetime probability of developing lung cancer, by smoking status, Canada. Can J Public Health 1994; 85: 385-8.

7. Khuder SA, Mutgi AB. Effect of smoking cessation on major histologic types of lung cancer. Chest 2001; 120: 1577-83

8. Tverdal A, Bjartveit K. Health consequences of reduced daily cigarette consumption. Tob Control 2006: 15: 472-80.

9. Taylor R, Najafi F, Dobson A. Meta-analysis of studies of passive smoking and lung cancer: effects of study type and continent. Int J Epidemiol 2007: 36: 1048-59.

10. Vineis $P$, Airoldi L, Veglia F et al. Environmental tobacco smoke and risk of respiratory cancer and chronic obstructive pulmonary disease in former smokers and never smokers in the EPIC prospective study. BMJ 2005: 330: 277

11. Darby S, Hill D, Auvinen A et al. Radon in homes and risk of lung cancer: collaborative analysis of individual data from 13 European case-control studies. BMJ 2005; 330: 223

12. Nelson HH, Kelsey KT. The molecular epidemiology of asbestos and tobacco in lung cancer. Oncogene 2002; 21: 7284-8. 
13. Schwartz AG, Prysak GM, Murphy V et al. Nuclear estrogen receptor beta in lung cancer: expression and survival differences by sex. Clin Cancer Res 2005; 11: $7280-7$.

14. Schwartz AG, Wenzlaff AS, Prysak GM et al. Reproductive factors, hormone use, estrogen receptor expression and risk of non small-cell lung cancer in women. J Clin Oncol 2007; 25: 5785-92.

15. Ishibashi H, Suzuki T, Suzuki S et al. Progesterone receptor in non-small cell lung cancer - a potent prognostic factor and possible target for endocrine therapy. Cancer Res 2005; 65: 6450-8.

16. Syrjanen KJ. HPV infections and lung cancer. J Clin Pathol 2002: 55: 885-91.

17. Chaturvedi AK, Kleinerman RA, Hildesheim A et al. Second cancers after squamous cell carcinoma and adenocarcinoma of the cervix. J Clin Oncol 2009; 27: 967-73

18. Lim WT, Chuah KL, Leong SS et al. Assessment of human papillomavirus and Epstein-Barr virus in lung adenocarcinoma. Oncol Rep 2009; 21: $971-5$.

19. Thun MJ, Hannan LM, Adams-Campbell LL et al. Lung cancer occurrence in never-smokers: an analysis of 13 cohorts and 22 cancer registry studies. PLoS Med 2008; 5: e185.

20. Hosgood HD 3rd, Berndt SI, Lan Q. GST genotypes and lung cancer susceptibility in Asian populations with indoor air pollution exposures: a meta-analysis. Mutat Res 2007; 636: 134-43.

21. Sun S, Schiller JH, Gazdar AF. Lung cancer in never smokers: a different disease. Nat Rev Cancer 2007: 7: 778-90.

22. Grimsrud TK, Berge SR, Haldorsen T et al. Can lung cancer risk among nickel refinery workers be explained by occupational exposures other than nickel? Epidemiology 2005: 16: 146-54.

23. Beelen R, Hoek G, van den Brandt PA et al. Longterm exposure to traffic-related air pollution and lung cancer risk. Epidemiology 2008; 19: 702-10.

24. Gorlova OY, Weng SF, Zhang Y et al. DNA repair capacity and lung cancer risk in never smokers.
Cancer Epidemiol Biomarkers Prev 2008; 17 . 1322-8

25. Amos Cl, Wu X, Broderick P et al. Genome-wide association scan of tag SNPs identifies a susceptibility locus for lung cancer at 15q25.1. Nat Genet 2008; 40: 616-22

26. Hung RJ, McKay JD, Gaborieau V et al. A susceptibility locus for lung cancer maps to nicotinic acetylcholine receptor subunit genes on $15 q 25$. Nature 2008; 452: 633-7.

27. Thorgeirsson TE, Geller F, Sulem $P$ et al. A variant associated with nicotine dependence, lung cancer and peripheral arterial disease. Nature 2008; 452: $638-42$.

28. Haugen A. Molekylærbiologisk diagnostikk ved lungekreft. Tidsskr Nor Lægeforen 2005; 125: 3283-5.

29. Balsara BR, Testa JR. Chromosomal imbalances in human lung cancer. Oncogene 2002; 21: 6877-83.

30. Wong MP, Lam WK, Wang E et al. Primary adenocarcinomas of the lung in nonsmokers show a distinct pattern of allelic imbalance. Cancer Res 2002; 62: 4464-8.

31. Shigematsu H, Gazdar AF. Somatic mutations of epidermal growth factor receptor signaling pathway in lung cancers. Int J Cancer 2006; 118 : 257-62.

32. Kosaka T, Yatabe Y, Endoh $\mathrm{H}$ et al. Mutations of the epidermal growth factor receptor gene in lung cancer: biological and clinical implications. Cancer Res 2004: 64: 8919-23.

33. Ahrendt SA, Decker PA, Alawi EA et al. Cigarette smoking is strongly associated with mutation of the K-ras gene in patients with primary adenocarcinoma of the lung. Cancer 2001; 92: 1525-30.

34. Stephens P. Hunter C. Bignell G et al. Lung cancer: intragenic ERBB2 kinase mutations in tumours. Nature 2004; 431: 525-6.

35. Mao L. Molecular abnormalities in lung carcinogenesis and their potential clinical implications. Lung Cancer 2001; 34 (suppl 2): S27-34.
36. Le Calvez F Mukeria A, Hunt JD et al. TP53 and KRAS mutation load and types in lung cancers in relation to tobacco smoke: distinct patterns in never, former, and current smokers. Cancer Res 2005: 65: 5076-83.

37. Divine KK, Pulling LC, Marron-Terada PG et al. Multiplicity of abnormal promoter methylation in lung adenocarcinomas from smokers and never smokers. Int J Cancer 2005: 114: 400-5.

38. Wang YC, Lu YP, Tseng RC et al. Inactivation of hMLH1 and hMSH2 by promoter methylation in primary non-small cell lung tumors and matched sputum samples. J Clin Invest 2003; 111: 887-95.

39. Dalmay T, Edwards DR. MicroRNAs and the hallmarks of cancer. Oncogene 2006; 25: 6170-5.

40. He L, He X, Lowe SW et al. microRNAs join the p53 network - another piece in the tumour-suppression puzzle. Nat Rev Cancer 2007; 7: 819-22.

41. Chin LJ, Ratner E, Leng $S$ et al. A SNP in a let-7 microRNA complementary site in the KRAS 3. untranslated region increases non-small cell lung cancer risk. Cancer Res 2008; 68: 8535-40.

42. Bryant A, Cerfolio RJ. Differences in epidemiology, histology, and survival between cigarette smokers and never-smokers who develop non-small cell lung cancer. Chest 2007; 132: 185-92.

43. Miller VA, Kris MG, Shah N et al. Bronchioloalveolar pathologic subtype and smoking history predict sensitivity to gefitinib in advanced non-smallcell lung cancer. J Clin Oncol 2004; 22: 1103-9.

44. Subramanian J, Govindan R. Lung cancer in never smokers: a review. J Clin Oncol 2007: 25: 561-70.

45. Shepherd FA, Rodrigues Pereira J, Ciuleanu T et al. Erlotinib in previously treated non-small-cell lung cancer. N Engl J Med 2005; 353: 123-32.

Manuskriptet ble mottatt 9.12. 2008 og godkjent 7.5. 2009. Medisinsk redaktør Michael Bretthauer. 